\title{
ANALISIS FAKTOR YANG MEMENGARUHI AGLOMERASI INDUSTRI UNGGULAN DAERAH DAN HUBUNGANNYA DENGAN DAYA SAING INDUSTRI DAERAH
}

\author{
Fikanti Zuliastri $^{1}$, Wiwiek Rindayati ${ }^{2}$, Alla Asmara ${ }^{2}$ \\ ${ }^{1}$ Mahasiswa Magister Program Studi Ilmu Ekonomi, FEM IPB \\ ${ }^{2}$ Staf Pengajar FEM IPB
}

Artikel diterima Juli 2013

Artikel disetujui untuk dipublikasikan Desember 2013

\begin{abstract}
The manufacturing industry sector is a major driver of economic growth in Indonesia with the largest contribution to the components of Gross Domestic Product is $25.60 \%$ in 2012. But the globalization and liberalization of international trade requires industries to be more competitive. Improving the competitiveness of the industry can be done through the development of regional-based industrial sector main industry that area. The purpose of this study was to analyze the competitiveness and industrial agglomeration, the causality relationship between competitiveness and agglomeration industry and the factors that influence agglomeration of province main industries. This study was using large and medium scale industry raw data. The data analysis using Location Quotient, Hoover Balassa Index, Granger Causality method and panel data method with Fixed Effect Model. The result of panel data regression shows factors that influence the agglomeration of province main industries are firm size, value added, the diversity of industry, industry competition index, competitiveness index, wages and road infastructure.
\end{abstract}

Keywords: Agglomeration, Granger Causality, Industrial Competitiveness, Panel Data

\section{PENDAHULUAN}

\section{Latar Belakang}

Pembangunan sektor industri merupakan bagian dari pembangunan ekonomi jangka panjang karena kontribusi sektor industri yang sangat besar terhadap pembentukan Produk Domestik Bruto (PDB) yaitu $25.60 \%$ khususnya industri non migas $23.86 \%$ pada tahun 2012. Akan tetapi jika dilihat perkembangannya, yaitu share pada tahun 2009 sebesar $26.16 \%$, tahun $2010(25.80 \%)$, tahun $2011(25.71 \%)$ dan tahun 2012 sebesar $25.60 \%$ maka kontribusi tersebut dari tahun ke tahun mengalami penurunan (BPS 2013). Hal ini menunjukkan pembangunan sektor industri mengalami penurunan dan terjadi penurunan daya saing sektor industri. Adanya globalisasi dan liberalisasi perdagangan internasional mengharuskan sektor industri berdaya saing tinggi agar dapat bersaing di era yang semakin kompetitif, khususnya dalam menghadapi Asean Economy Community (AEC) pada tahun 2015. 
Tabel 1 Distribusi Persentase Produk Domestik Bruto (PDB) Atas Dasar Harga Konstan Menurut Lapangan Usaha Tahun 2009-2012

\begin{tabular}{lrrrr}
\hline \multicolumn{1}{c}{ Lapangan Usaha } & $\mathbf{2 0 0 9}$ & $\mathbf{2 0 1 0}$ & $\mathbf{2 0 1 1}$ & $\mathbf{2 0 1 2}$ \\
\hline 1. Pertanian, Peternakan, Kehutanan & 13,58 & 13,17 & 12,78 & 12,51 \\
$\quad$ dan Perikanan & & & & \\
2. Pertambangan dan Penggalian & 8,27 & 8,09 & 7,70 & 7,36 \\
3. Industri Pengolahan & $\mathbf{2 6 , 1 6}$ & $\mathbf{2 5 , 8 0}$ & $\mathbf{2 5 , 7 1}$ & $\mathbf{2 5 , 6 0}$ \\
a. Industri Migas & 2,15 & 2,04 & 1,90 & 1,74 \\
b. Industri Non Migas & $\mathbf{2 4 , 0 1}$ & $\mathbf{2 3 , 7 6}$ & $\mathbf{2 3 , 8 1}$ & $\mathbf{2 3 , 8 6}$ \\
4. Listrik, Gas dan Air Minum & 0,79 & 0,78 & 0,77 & 0,77 \\
5. Bangunan (Konstruksi) & 6,44 & 6,48 & 6,49 & 6,57 \\
6. Perdagangan, Hotel dan Restoran & 16,91 & 17,30 & 17,74 & 18,05 \\
7. Pengangkutan dan Komunikasi & 8,82 & 9,42 & 9,79 & 10,14 \\
8. Keuangan dan Real Estate & 9,60 & 9,55 & 9,58 & 9,66 \\
9. Jasa-Jasa & 9,43 & 9,41 & 9,43 & 9,35 \\
\hline
\end{tabular}

Sumber : Badan Pusat Statistik 2013

Menurut Global Competitiveness Report pada tahun 2013 daya saing Indonesia berada pada peringkat ke 38 dari 144 negara yang disurvei. Rendahnya daya saing Indonesia disebabkan adanya peningkatan biaya energi dan tingginya biaya ekonomi terkait dengan belum memadainya ketersediaan infrastruktur jalan dan layanan birokrasi. Masalah layanan birokrasi terkait dengan pelaksanaan pelayanan satu pintu yang dapat memudahkan kegiatan industri dalam hal perizinan dan penanaman modal. Ketersediaan infrastruktur dan kondisi layanan birokrasi tersebut akan sangat berdampak pada biaya produksi yang harus dikeluarkan industri yang pada akhirnya akan memengaruhi daya saing industri. Selain itu, rendahnya daya saing industri dikarenakan pembangunan industri belum sepenuhnya berbasis pada potensi unggulan daerah.

Berdasarkan permasalahan kondisi daya saing industrimaka pembangunan industri nasional harus dilakukan secara sinergi antara perencanaan di tingkat pusat dan daerah. Hal ini dilakukan dengan dua pendekatan, yakni pendekatan top down dan pendekatan bottom up. Pendekatan top down merupakan pembangunan industri dengan memperhatikan prioritas yang ditentukan secara nasional berdasarkan kemampuan untuk bersaing di pasar domestik dan internasional dan diikuti oleh partisipasi daerah. Adapun pendekatan bottom up merupakan pengembangan industri komoditi unggulan daerah melalui pemberdayaan produk industri unggulan daerah.

Masalah lain yang terjadi yaitu sumber daya yang ada jumlahnya terbatas dan tersebar secara tidak merata antardaerah sehingga menyebabkan tiap daerah memiliki potensi sumberdaya yang berbeda. Dengan potensi sumberdaya yang berbeda di masingmasing daerah maka perlu ditentukan industri-industri unggulan daerah sesuai dengan potensi yang dimiliki tiap daerah. Selain itu, perbedaan potensi sumberdaya antardaerah akan mendorong terjadinya mobilitas faktor produksi seperti tenaga kerja dan kapital. Kecenderungan pergerakan faktor produksi akan mengakibatkan 
beberapa daerah memiliki kegiatan industri yang lebih besar dan terjadi pengelompokan pada daerah tertentu. Pemusatan kegiatan di dalam suatu wilayah akan memberikan keuntungan, yaitu keuntungan akibat aglomerasi. Keuntungan dari aglomerasi diperoleh karena lokasi yang saling berdekatan antar industri sehingga terjadi penghematan biaya produksi. Pendekatan aglomerasi dapat meningkatkan daya saing dan menciptakan kekuatan industri nasional dalam bentuk saling ketergantungan, keterkaitan dan saling menunjang antara industri hulu, industri hilir, industri pendukung dan industri terkait (Tambunan 2001).

Vidyatmoko et al (2011) menyatakan bahwa salah satu penguat daya saing nasional adalah adanya efisiensi produksi pada kegiatan industri. Efisiensi produksi lebih mudah dicapai dengan terjadinya aglomerasi industri karena faktor produksi yang dibutuhkan (tenaga kerja) akan terkonsentrasi di lokasi tersebut. Selain itu, dengan teraglomerasinya industri transfer pengetahuan menjadi lebih mudah sehingga produktivitas industri dapat meningkat dan mempercepat pertumbuhan industri. Sektor industri pengolahan di Indonesia 55\% teraglomerasi di Provinsi Jawa Barat dengan nilai tambah yang dihasilkan merupakan yang terbesar yaitu mencapai Rp 272 triliun (Kemenperin 2011). Sebagai bukti empiris, aglomerasi industri terjadi pada industri tekstil dan produk tekstil dan industri kerajinan kayu di Provinsi Jawa Tengah. Aglomerasi industri tersebut terbukti mampu meningkatkan pembangunan sektor industri dan memudahkan transfer pengetahuan dan teknologi. Berdasarkan hal tersebut maka dalam rangka meningkatkan daya saing sektor industri maka pembangunan industri nasional harus dilakukan dengan mengkombinasikan antara pendekatan sektoral yakni mengembangkan aglomerasi industri dengan pendekatan regional yang berlandaskan pada keunggulan komparatif yang dimiliki masingmasing daerah.

Daerah-daerah yang banyak perekonomiannya akan tumbuh lebih cepat dibandingkan daerah-daerah yang hanya memiliki sedikit industri manufaktur. Hal ini dikarenakan daerah-daerah yang mempunyai industri manufaktur akan memiliki lebih banyak akumulasi modal. Menurut Landiyanto (2005) perkembangan industri melalui pendekatan aglomerasi dilakukan karena beberapa alasan, yaitu (1) Membantu industri untuk mencapai skala ekonomi yang optimal melalui aglomerasi tersebut; (2) Memudahkan transfer pengetahuan dan teknologi; daan (3) Menciptakan lingkungan yang dapat menumbuhkan inovasi dan kerja sama antar industri. Dengan demikian, semakin teraglomerasi secara spasial suatu kegiatan industri maka akan semakin meningkat pertumbuhannya. Hal yang sama diungkapkan oleh Kuncoro (2004) bahwa pengembangan sektor industri yang berbasis pada potensi dan sumberdaya yang dimiliki tiap daerah dengan dibarengi pendekatan aglomerasi merupakan suatu langkah strategis untuk meningkatkan daya saing industri. 
Tabel 2 Laju Pertumbuhan Ekonomi pada Daerah Pusat Pertumbuhan Industri di Indonesia Tahun 2009-2012 (\%)

\begin{tabular}{lllll}
\hline Provinsi & $\mathbf{2 0 0 9}$ & $\mathbf{2 0 1 0}$ & $\mathbf{2 0 1 1}$ & $\mathbf{2 0 1 2}$ \\
\hline DKI Jakarta & 5,02 & 6,50 & 6,73 & 6,53 \\
Jawa Barat & 4,19 & 6,20 & 6,48 & 6,21 \\
Jawa Tengah & 5,14 & 5,84 & 6,03 & 6,34 \\
DI Yogyakarta & 4,43 & 4,88 & 5,17 & 5,32 \\
Jawa Timur & 5,01 & 6,68 & 7,22 & 7,27 \\
Banten & 4,71 & 6,11 & 6,39 & 6,15 \\
\hline Indonesia & 4,77 & 6,22 & 6,49 & 6,23 \\
\hline
\end{tabular}

Sumber : Badan Pusat Statistik 2013

Perkembangan sektor industri merupakan prioritas utama dalam rencana pembangunan suatu negara karena peran sektor industri sebagai leading sector dalam mendukung sektor lainnya. Daya saing industri lebih mudah ditingkatkan apabila industri berkelompok sehingga terjadi penghematan. Oleh karena itu, untuk meningkatkan daya saing industri perlu dilakukan aglomerasi industri. Pelaksanaan aglomerasi industri membutuhkan strategi yang tepat agar aglomerasi industri tersebut dapat berkontribusi besar terhadap perekonomian daerah.

\section{Tujuan Penelitian}

Penelitian ini dilakukan pada tingkat provinsi dengan pertimbangan bahwa dalam era otonomi daerah dan desentralisasi fiskal, provinsi memiliki peran yang paling penting dalam menentukan keberhasilan pembangunan nasional dengan peran provinsi yaitu sebagai penentu kebijakan di tingkat regional (provinsi) dan sebagai perencana pembangunan ekonomi regional. Secara umum tujuan dari penelitian ini adalah sebagai berikut:

1. Menjelaskan profil industri-industri yang menjadi industri unggulan di masing-masing provinsi di Indonesia.
2. Menganalisis kondisi daya saing dan aglomerasi industri unggulan provinsi di Indonesia.

3. Menganalisis hubungan kausalitas antara aglomerasi dan daya saing industri unggulan provinsi.

4. Menganalisis faktor - faktor yang dapat memengaruhi aglomerasi industri unggulan provinsi.

\section{TINJAUAN PUSTAKA}

\section{Aglomerasi Industri}

Dalam konteks ekonomi geografi, konsep aglomerasi berkaitan dengan konsentrasi spasial dari kegiatan-kegiatan ekonomi. Hal ini sejalan dengan yang dikemukakan Kuncoro (2002) bahwa aglomerasi adalah konsentrasi spasial dari aktivitas ekonomi karena penghematan akibat lokasi yang berdekatan yang diasosiasikan dengan klaster spasial dari perusahaan, para pekerja dan konsumen. Keuntungan-keuntungan yang diperoleh dari konsentrasi spasial akibat skala ekonomi (economies of scale) disebut dengan ekonomi aglomerasi (agglomeration economies). Pengertian ekonomi aglomerasi berkaitan dengan eksternalitas kedekatan geografis dari kegiatan-kegiatan ekonomi. Ekonomi aglomerasi merupakan bentuk dari eksternalitas positif dalam produksi 
yang merupakan salah satu faktor pendorong terjadinya pertumbuhan daerah. Ekonomi aglomerasi diartikan sebagai penurunan biaya produksi karena kegiatan-kegiatan ekonomi berlokasi pada tempat yang sama. Menurut Kolehmainen (2002) aglomerasi berarti industri tidak berlokasi secara merata pada seluruh wilayah, akan tetapi mengelompok secara berdekatan pada bagian tertentu di wilayah tersebut. Dalam aglomerasi industri terdapat interaksi yang saling terkait antara skala ekonomi, biaya transportasi dan permintaan. Untuk meningkatkan kekuatan skala ekonomis, industri cenderung beraglomerasi secara spasial dan melayani seluruh pasar dari suatu lokasi.

Menurut Landiyanto
aglomerasi berkaitan
konsentrasi dari beberapa fasilitas
pendukung yang melayani industri-
industri dengan keberadaan fasilitas
tersebut dapat memengaruhi terjadinya
aglomerasi. Fasilitas pendukung
tersebut antara lain transportasi, ketersediaan tenaga kerja dengan keahlian yang beraneka ragam dan pelayanan dari pemerintah. Faktor yang menentukan pemilihan lokasi industri yaitu adanya perbedaan biaya transportasi, perbedaan biaya upah dan penghematan aglomerasi. Produsen cenderung memilih lokasi yang memberikan keuntungan berupa penghematan biaya transportasi sehingga dapat mendorong efisiensi dan efektivitas produksi. Selain itu, produsen cenderung mencari lokasi dengan tingkat upah tenaga kerja yang lebih rendah untuk meminimalkan biaya yang dikeluarkan.

\section{Perbedaan Aglomerasi dengan Kluster Industri}

Aglomerasi merupakan proses yang lebih kompleks jika dibandingkan kluster industri. Perbedaan antara aglomerasi industri dan klaster industri terletak pada skala ekonomi dan keanekaragaman industri. Skala ekonomi dan keanekaragaman industri (industrial diversity) merupakan peran penting dalam pembentukan dan pertumbuhan aglomerasi. Industri yang terkonsentrasi secara geografis disebabkan karena skala ekonomi. Sedangkan keanekaragaman industri mendorong eksplorasi dan mencegah stagnasi sehingga berperan dalam penyebaran pengetahuan (knowledge spillover) dan pertumbuhan regional. Adanya keragaman industri menunjukkan terjadinya aglomerasi karena produk lebih heterogen (Kuncoro 2002). Perbedaan antara aglomerasi industri dan klaster industri terlihat pada output yang dihasilkan. Klaster industri merupakan kumpulan industri sejenis yang secara geografis terkonsentrasi di suatu lokasi karena adanya keuntungan atau penghematan akibat lokalisasi dan spesialisasi sehingga menghasilkan output yang lebih homogen. Sedangkan aglomerasi industri terbentuk karena berkumpulnya beragam industri pada suatu lokasi tertentu yang akhirnya akan menghasilkan output yang heterogen. Kluster dan aglomerasi menjadi semakin berkembang tidak hanya karena industri-industri yang ada didalamnya tetapi didukung pula oleh organisasi yang terkait sehingga dapat meningkatkan daya saing berdasarkan keunggulan kompetitif (Santoso dan Prabatmodjo 2012). Salah satu ciri penting di dalam aglomerasi ialah tumbuhnya industri-industri yang menggunakan teknologi lebih maju, berkembangnya spesialisasi proses produksi pada perusahaan-perusahaan tersebut, dan kegiatan ekonomi antarindustri yang saling terkait dan saling mendukung. 


\section{Penghematan Aglomerasi}

Pada dasarnya aglomerasi industri merupakan pengelompokan industri inti yang saling berhubungan dengan industri pendukung (supporting industries), industri terkait (related industries), jasa penunjang maupun infrastruktur ekonomi. Oleh karena itu, strategi pengembangan industri yang tepat untuk membangun daya saing industri yang berkelanjutan dilakukan melalui pendekatan agomerasi. Hal ini dikarenakan kegiatan-kegiatan pada sektor industri memiliki keterkaitan yang erat dengan kegiatan-kegiatan di sektor lain baik keterkaitan ke belakang (backward linkages) maupun keterkaitan ke depan (forward linkages). Apabila kegiatan-kegiatan tersebut dilakukan pada suatu kawasan tertentu (beraglomerasi), maka dapat mengurangi biaya transportasi dan berbagai biaya lainnya atau biaya transaksi (Deichmann et al 2005). Aglomerasi yang baik ditunjukkan oleh tingginya tingkat keterkaitan berbagai kegiatan yang saling mendukung antara satu pelaku dengan pelaku yang lain. Agar hal tersebut dapat terwujud, maka dari sisi pemerintah perlu mempersiapkan dukungan infrastruktur ekonomi yang memadai. Hal ini karena infrastruktur yang baik akan mendorong kelancaran interaksi antara industriindustri terkait dan mampu meningkatkan efisiensi biaya sehingga dapat meningkatkan daya saing industri.

Penghematan aglomerasi terjadi akibat terkonsentrasinya aktivitas ekonomi secara spasial. Penghematan tersebut dapat terjadi di dalam industri yang sama ataupun beberapa industri yang berbeda. Menurut Capello (2007) penghematan aglomerasi dikategorikan menjadi tiga macam, yaitu penghematan karena skala ekonomi (economies of scale), penghematan lokalisasi (localization economies) dan penghematan urbanisasi (urbanization economies). Economies of scale terjadi karena adanya proses produksi dalam skala besar sehingga berdampak pada penurunan biaya per unit output (average cost). Penghematan lokalisasi terjadi karena konsentrasi spasial dalam industri yang sama yang meliputi penghematan transfer yang terjadi pada seluruh perusahaan dalam industri yang saling terkait. Adapun penghematan urbanisasi terjadi karena industri berlokasi pada unit pemukiman yang besar. Penghematan tersebut berupa keekonomisan kota yaitu efisiensi ekonomi akibat tersedianya infrastruktur kota, tenaga kerja, energi listrik, sistem telekomunikasi canggih dan sarana/prasarana serta fasilitas umum yang tersedia. Penghematan ini meningkat seiring dengan peningkatan ukuran fisik kota.

\section{Tinjauan Empiris}

Penelitian mengenai aglomerasi industri manufaktur sebelumnya telah dilakukan oleh Landiyanto (2005), Kuncoro dan Wahyuni (2009) dan Purwaningsih (2011). Landiyanto (2005) melakukan kajian konsentrasi spasial industri manufaktur di Kota Surabaya dengan menggunakan data tenaga kerja industri manufaktur dua digit per kecamatan di Surabaya dari tahun 1994 hingga 2002. Data tersebut dianalisis menggunakan metode LQ dan hasilnya menunjukkan bahwa industri manufaktur di Kota Surabaya teraglomerasi di Kecamatan Rungkut, Tandes dan Sawahan dengan subsektor unggulan Kota Surabaya adalah industri makanan, minuman dan tembakau serta industri logam, mesin dan peralatan. Sementara itu Kuncoro dan Wahyuni (2009) menganalisis faktor-faktor yang menentukan aglomerasi sektor industri manufaktur di Pulau Jawa. Metode yang digunakan yaitu panel data dengan 
periode tahun 1991 hingga 2002 dengan variabel terikat yang digunakan sebagai ukuran aglomerasi yaitu Indeks Spesialisasi (LQ). Hasil penelitian menyimpulkan bahwa kandungan impor, skala ekonomi, orientasi ekspor, indeks persaingan, pendapatan per kapita dan upah tenaga kerja berpengaruh signifikan pada pembentukan aglomerasi. Adapun faktor-faktor yang memengaruhi aglomerasi industri besar sedang di Jawa Barat diteliti oleh Purwaningsih (2011) dengan periode 2001-2008. Hasil penelitian menunjukan bahwa faktor-faktor yang secara positif memengaruhi aglomerasi industri yaitu ukuran perusahaan, keanekaragaman industri, kepemilikan modal asing, besarnya pasar dan infrastruktur jalan. Sedangkan faktor yang berpengaruh secara negatif adalah tingkat upah dan kebijakan kenaikan Bahan Bakar Minyak (BBM).

\section{METODE PENELITIAN}

\section{Jenis dan Sumber Data}

Data yang digunakan dalam penelitian ini adalah data sekunder berupa data panel yang merupakan gabungan data cross section dan data time series. Periode waktu yang digunakan yaitu tahun 2004-2011. Adapun untuk data cross section yang digunakan mencakup 33 provinsi di Indonesia dengan 20 provinsi memiliki satu jenis industri unggulan dan 13 provinsi memiliki dua jenis industri unggulan. Dengan demikian jumlah data cross section yang digunakan menjadi 46 industri unggulan provinsi. Data industri manufaktur yang digunakan dalam analisis dibatasi hanya industri skala besar dan sedang dan yang merupakan industri unggulan di masing-masing provinsi. Industri unggulan provinsi yang digunakan adalah industri yang termasuk dalam klasifikasi ISIC 5 digit. Data-data yang digunakan dalam penelitian ini bersumber dari Badan Pusat Statistik (BPS), Kementerian Perindustrian dan Badan Koordinasi Penanaman Modal.

\section{Metode Location Quotient (LQ)}

Ukuran yang digunakan sebagai indikator daya saing yaitu nilai tambah, penyerapan tenaga kerja, profitabilitas, produktivitas, dan efisiensi dalam penggunaan input atau efisiensi biaya. Akan tetapi, metode yang sering digunakan untuk mengetahui industri yang memiliki daya saing yang tinggi (unggulan) yaitu analisis LQ yang berbasis pada output yang dihasilkan (Santoso dan Ferdyansyah 2013).

$$
\mathrm{LQ}_{\mathrm{it}}=\frac{W_{i t} / W t}{Y i t / Y t}
$$

Keterangan :

$\mathrm{W}_{\text {it }}$ : Output industri unggulan di provinsi i pada tahun $\mathrm{t}$

$\mathrm{W}_{\mathrm{t}}$ : Output total semua industri di provinsi i pada tahun $\mathrm{t}$

$Y_{\text {it }}$ : Output industri unggulan provinsi i di tingkat nasional pada tahun $\mathrm{t}$

$\mathrm{Y}_{\mathrm{t}}$ : Output total semua industri di tingkat nasional pada tahun $\mathrm{t}$

Jika hasil perhitungan menghasilkan nilai LQ > 1, maka industri tersebut tergolong berdaya saing. Hal ini menunjukkan bahwa pangsa output industri unggulan di tingkat provinsi tersebut lebih besar dibandingkan di tingkat nasional. Sebaliknya, jika nilai LQ < 1, maka industri tersebut tergolong tidak berdaya saing.

\section{Indeks Hoover Balassa}

Salah satu pendekatan yang digunakan dalam menganalisis konsentrasi spasial suatu industri yaitu Hoover Balassa Index (HBI). Indeks 
Hoover Balassa merupakan ukuran untuk mengetahui suatu industri teraglomerasi pada suatu wilayah. Peningkatan indeks pada suatu industri menunjukkan terjadinya peningkatan spesialisasi industri di daerah tersebut. Indeks Hoover Balassa ini menyatakan bahwa spesialisasi industri terjadi apabila share industri pada suatu wilayah lebih besar daripada share industri pada wilayah agregat. Industri akan teraglomerasi pada suatu lokasi dimana share tenaga kerja untuk industri tersebut lebih besar daripada share tenaga kerja industri secara agregat (Tian 2013). Rumus untuk perhitungan indeks Hoover Balassa dapat dituliskan sebagai berikut:

$$
\mathrm{HBI}_{\mathrm{it}}=\frac{S_{i t}}{X_{i t}}
$$

Keterangan :

$\mathrm{S}_{\mathrm{it}}$ : Share tenaga kerja industri unggulan provinsi i terhadap total tenaga kerja industri provinsi i pada tahun $\mathrm{t}$.

$\mathrm{X}_{\mathrm{it}}$ : Share tenaga kerja industri unggulan provinsi $\mathrm{i}$ di tingkat nasional pada tahun $t$.

Nilai HBI > 1 menunjukkan bahwa industri unggulan tersebut teraglomerasi pada suatu wilayah karena share tenaga kerja industri unggulan provinsi tersebut lebih besar dibandingkan share di tingkat nasional (secara agregat). Sebaliknya jika nilai HBI $<1$ menunjukkan industri tersebut tidak teraglomerasi.

\section{Metode Kausalitas Granger}

Variabel ekonomi seringkali tidak hanya mempunyai hubungan satu arah namun juga dapat menunjukkan hubungan dua arah yang bersifat kausalitas atau saling memengaruhi. Salah satu metode yang dapat digunakan untuk mendeteksi hubungan kausalitas adalah metode Kausalitas
Granger (Granger Causality). Uji kausalitas Granger dapat mendeteksi apakah antar variabel hanya mempunyai hubungan satu arah atau justru terjadi hubungan dua arah yakni saling memengaruhi (Gujarati 2004). Dalam penelitian ini dianalisis apakah daya saing menjadi salah satu faktor yang memengaruhi aglomerasi industri. Tetapi, terdapat kemungkinan bahwa aglomerasi juga memengaruhi daya saing industri unggulan provinsi di Indonesia. Oleh karena itu, hubungan antara aglomerasi industri dan daya saing industri dianalisis dengan menggunakan metode Kausalitas Granger pada panel data.

\section{Metode Regresi Panel Data}

Regresi panel data merupakan metode regresi yang menggabungkan data cross section dan data time series sehingga yang diamati adalah unit-unit individu yang sama dalam kurun waktu tertentu. Secara umum, data panel dicirikan oleh $\mathrm{T}$ periode waktu $(\mathrm{t}=1,2, \ldots, \mathrm{T})$ yang kecil dan $\mathrm{N}$ jumlah individu $(\mathrm{i}=1,2, \ldots, \mathrm{N})$ yang besar. Metode panel data dapat menangkap perilaku sejumlah individu yang memiliki karakteristik yang berbedabeda dalam suatu rentang waktu yang terdiri atas unit-unit waktu yang juga berbeda. Heterogenitas antar individu maupun antar waktu ditunjukkan dalam model dengan intersep dan koefisien slope yang berbeda-beda. Menurut Baltagi (2005) keunggulan menggunakan metode regresi panel data, yaitu antara lain:

1. Data panel mampu mendeteksi dan mengukur efek yang secara sederhana tidak dapat diperoleh dengan data cross section murni atau data time series murni.

2. Mampu mengontrol heterogenitas individu dan mengurangi kolinearitas antar variabel. 
3. Dapat meminimalkan bias yang dihasilkan oleh agregasi individu karena unit data yang diobservasi lebih banyak serta meningkatkan derajat bebas.

4. Memiliki fleksibilitas yang lebih besar dalam memodelkan perbedaan perilaku di antara individu-individu yang diobservasi.

Pada penelitian ini metode regresi panel data digunakan untuk menganalisis faktor-faktor yang memengaruhi aglomerasi industri unggulan provinsi.

\section{Spesifikasi Model}

Model yang digunakan untuk menganalisis faktor-faktor yang memengaruhi aglomerasi industri unggulan provinsi didasarkan pada model yang digunakan Kuncoro dan Wahyuni (2009), Alkay dan Hewings (2010) dan Purwaningsih (2011). Variabel bebas yang digunakan terdiri atas karakteristik industri (spesifik industri) dan karakteristik regional (spesifik regional) yang ditambahkan dengan variabel infrastruktur. Dengan demikian model regresi yang digunakan adalah sebagai berikut:

$$
\begin{aligned}
& \mathrm{HBI}_{\mathrm{it}}=\mathrm{a}_{\mathrm{it}}+\mathrm{a}_{1} \operatorname{lnSIZ} \mathrm{it}_{\mathrm{it}}+\mathrm{a}_{2} \mathrm{RID}_{\mathrm{it}}+\mathrm{a}_{3} \\
& \mathrm{INVEST}_{\text {it }}+\mathrm{a}_{4} \operatorname{lnNT} \mathrm{lit}_{\mathrm{it}}+\mathrm{a}_{5} \mathrm{IPS}_{\mathrm{it}} \\
& +\mathrm{a}_{6} \mathrm{LQ}_{\mathrm{it}}+\mathrm{b}_{1} \ln \mathrm{UMP}_{\mathrm{it}}+\mathrm{b}_{2} \\
& \ln \text { PDRBPK }_{\text {it }}+\mathrm{b}_{3} \ln _{\mathrm{it}}+\mathrm{b}_{4} \\
& \text { DUMPTSP }_{i}+e_{i t}
\end{aligned}
$$

Keterangan :

$\mathrm{HBI}_{\mathrm{it}}$ : Indeks aglomerasi industri pada industri unggulan i dan tahun $\mathrm{t}$.

SIZ $_{\text {it }}$ : Ukuran perusahaan berdasarkan rata-rata jumlah tenaga kerja industri unggulan i pada tahun $\mathrm{t}$.

$$
\mathrm{SIZ}_{\mathrm{it}}=\frac{\text { Jumlah tenaga kerja industri unggulan }}{\text { Jumlah perusahaan industri unggulan }}
$$
$\mathrm{RID}_{\mathrm{it}}$ : Indeks relative industrial diversity yaitu ukuran untuk melihat keanekaragaman jenis industri yang ada di provinsi i pada tahun $\mathrm{t}$.

$$
\mathrm{RID}_{\mathrm{ijt}}=\frac{\sum_{h \neq j}\left(L_{i h t} / L_{i t}\right)^{2}}{\sum_{h \neq j}\left(L_{h t} / L_{t}\right)^{2}}
$$

$\mathrm{L}$ adalah tenaga kerja, i adalah provinsi, $\mathrm{j}$ adalah industri unggulan, $\mathrm{h}$ adalah industri lainnya selain industri unggulan dan $\mathrm{t}$ adalah waktu.

INVEST $_{\text {it }}$ : Proporsi total investasi asing dan dalam negeri terhadap PDRB di provinsi i pada tahun $t$.

$\mathrm{NT}_{\text {it }}$ : Nilai tambah yang dihasilkan oleh industri unggulan i pada tahun $\mathrm{t}$.

IPS $_{\text {it }}$ : Indeks persaingan industri yang digunakan untuk memproksi struktur pasar di provinsi i pada tahun $\mathrm{t}$.

IPS $_{\text {it }}=\frac{(\text { jumlah perusahaan } / \text { nilai output })_{\text {it }}}{(\text { jumlah perusahaan } / \text { nilai output })_{\mathrm{t}}}$

$\mathrm{LQ}_{\text {it }} \quad$ : Nilai indeks daya saing industri unggulan i pada tahun $\mathrm{t}$.

$\mathrm{UMP}_{\text {it }}$ : $\quad$ Upah minimum provinsi yang ditetapkan di provinsi i pada tahun $t$.

PDRBPK $_{\mathrm{it}}$ : Pendapatan regional per kapita di provinsi i pada tahun t.

$\mathrm{J}_{\mathrm{it}} \quad$ : $\quad$ Infrastruktur jalan yaitu panjang jalan beraspal dengan kondisi baik dan sedang yang meliputi jalan negara, provinsi dan jalan kabupaten di provinsi i pada tahun $t$.

DUMPTSP $P_{\mathrm{i}}$ : Dummy dari pelaksanaan Pelayanan Terpadu Satu Pintu (PTSP) di provinsi i. Dummy bernilai 0 
untuk tahun sebelum tahun pelaksanaan PTSP dan nilai 1 untuk tahun pelaksanaan dan tahun setelah pelaksanaan PTSP.

\section{* Uji Pemilihan Model}

Dalam menentukan model panel data terbaik yang digunakan, harus dilakukan suatu pengujian pemilihan model. Pengujian model terbaik dilakukan dengan uji Hausman dan uji Chow.

1. Uji Hausman dilakukan untuk menentukan model terbaik antara model Fixed Effect dan model Random Effect. Hipotesis yang digunakan pada uji Hausman yaitu :

$\mathrm{H}_{0}$ : Model random effect

$\mathrm{H}_{1}$ : Model fixed effect

Jika nilai statistik Hausman hasil pengujian lebih besar dari ChiSquare tabel, maka cukup bukti untuk memutuskan tolak $\mathrm{H}_{0}$ sehingga model terbaik yang digunakan yaitu fixed effect model.

2. Uji Chow dilakukan untuk menentukan model terbaik antara model Fixed Effect dan model Pooled Least Square (PLS). Hipotesis yang digunakan pada uji Chow yaitu:

$$
\begin{aligned}
& \mathrm{H}_{0} \text { : Model Pooled Least Square } \\
& \mathrm{H}_{1} \text { : Model fixed effect }
\end{aligned}
$$

Jika hasil dari uji Chow menunjukkan nilai probabilitas kurang dari taraf nyata $(\alpha)$, maka keputusannya $\mathrm{H}_{0}$ ditolak sehingga model terbaik yang digunakan adalah fixed effect model.

\section{Uji Kesesuaian Model}

1. $\mathrm{Uji}-\mathrm{F}$

$\mathrm{Uji}-\mathrm{F}$ adalah statistik uji yang digunakan untuk mengetahui pengaruh variabel bebas terhadap variabel terikat secara keseluruhan. Hipotesisnya yaitu:

$$
\begin{aligned}
& \mathrm{H}_{0}: \beta_{1}=\beta_{2}=\ldots=\beta_{\mathrm{t}}=0 \\
& \mathrm{H}_{1}: \text { minimal ada satu } \beta_{\mathrm{t}} \neq 0
\end{aligned}
$$

Jika nilai probabilitas $F$-statistic < taraf nyata $(\alpha)$, maka keputusannya $\mathrm{H}_{0}$ ditolak sehingga kesimpulannya adalah minimal ada satu variabel bebas yang memengaruhi variabel terikat.

2. $\mathrm{Uji}-\mathrm{t}$

Dalam penelitian ini uji $-\mathrm{t}$ digunakan untuk mengetahui pengaruh masing-masing variabel bebas yang menjadi faktor-faktor dalam memengaruhi aglomerasi industri. Hipotesis dalam uji - $\mathrm{t}$ yaitu:

$$
\begin{aligned}
& \mathrm{H}_{0}: \beta_{\mathrm{t}}=0 \text { dengan } \mathrm{t}=1,2,3, \ldots, \mathrm{n} \\
& \mathrm{H}_{1}: \beta_{\mathrm{t}} \neq 0
\end{aligned}
$$

Jika nilai probabilitas $t$-statistic < taraf nyata $(\alpha)$, maka keputusannya tolak $\mathrm{H}_{0}$. Dengan demikian dapat disimpulkan variabel bebas yang diuji berpengaruh signifikan terhadap aglomerasi industri unggulan.

3. $\mathrm{Uji} \mathrm{R}^{2}$

Uji koefisien determinasi atau uji $\mathrm{R}^{2}$ dilakukan untuk mengukur besarnya keragaman variabel terikat yang mampu dijelaskan oleh variabel-variabel bebas yang terdapat di dalam model. Nilai $\mathrm{R}^{2}$ berkisar antara 0 sampai 1 . Nilai $R^{2}$ yang semakin mendekati 1 menunjukkan semakin baik keragaman variabel terikat yang mampu dijelaskan oleh variabel-variabel bebas tersebut.

\section{HASIL DAN PEMBAHASAN}

\section{Penentuan Industri Unggulan Provinsi}

Berdasarkan Peraturan Presiden No. 28 tahun 2008 tentang Kebijakan Industri Nasional dalam Pasal 3 dijelaskan mengenai pengembangan kompetensi inti industri daerah untuk meningkatkan daya saing dalam rangka meningkatkan perekonomian daerah. Langkah yang dilakukan untuk pengembangan kompetensi inti industri daerah salah satunya dengan 
mengembangkan industri unggulan provinsi. Penentuan industriunggulan di tiap provinsi dilakukan oleh pemerintah provinsi dengan menyusun peta panduan pengembangan industri unggulan provinsi. Penentuan industri unggulan tersebut didasarkan pada indikator-indikator ekonomi yaitu penyerapan tenaga kerja, volume produksi, nilai tambah dan potensi pasar. Jenis industri unggulan provinsi yang telah ditentukan selanjutnya diusulkan pada Kementerian Perindustrian untuk dikaji dan dievaluasi.

Tabel 3 Jenis Industri Unggulan pada Provinsi dengan Satu Industri Unggulan

\begin{tabular}{llllll}
\hline No & \multicolumn{1}{c}{ Provinsi } & Industri Unggulan & No & Provinsi & Industri Unggulan \\
\hline 1. & Aceh & Minyak Atsiri & 11. & NTB & Industri Kerajinan \\
2. & Sumatera Barat & Industri Kakao & 12. & NTT & Industri Kakao \\
3. & Sumatera & Industri Karet & 13. & Kalteng & Industri Rotan \\
& Selatan & & 14. & Sulteng & Industri Hasil Laut \\
4. & Bengkulu & Industri Karet & 15. & Sultra & Industri Hasil Laut \\
5. & Lampung & Industri Ubi Kayu & 16. & Sulawesi & Industri Kakao \\
6. & Kepulauan & Industri Perkapalan & & Barat & \\
& Riau & & 17. & Gorontalo & Industri Perikanan \\
7. & DKI Jakarta & Kerajinan Kayu & 18. & Maluku & Industri Hasil Laut \\
8. & Jawa Barat & IndustriTekstil & 19. & Maluku & Industri Kelapa \\
9. & Banten & Industri Tekstil & 20. & Utara & Industri Kopi \\
10. & Bali & Kerajinan Barang & & Papua & \\
& & Seni & & & \\
\hline
\end{tabular}

Sumber : Kementerian Perindustrian 2010

Tabel 4 Jenis Industri Unggulan pada Provinsi dengan Dua Industri Unggulan

\begin{tabular}{|c|c|c|c|c|c|}
\hline No & Provinsi & Industri Unggulan & No & Provinsi & Industri Unggulan \\
\hline 1. & Sumatera Utara & $\begin{array}{l}\text { Industri Karet } \\
\text { Industri Kelapa Sawit }\end{array}$ & 8. & $\begin{array}{l}\text { Kalimantan } \\
\text { Barat }\end{array}$ & $\begin{array}{l}\text { Industri Kelapa Sawit } \\
\text { Industri Karet }\end{array}$ \\
\hline 2. & Riau & $\begin{array}{l}\text { Industri Kelapa Sawit } \\
\text { Industri Kelapa }\end{array}$ & 9. & $\begin{array}{l}\text { Kalimantan } \\
\text { Selatan }\end{array}$ & $\begin{array}{l}\text { Industri Kelapa Sawit } \\
\text { Industri Batu Mulia }\end{array}$ \\
\hline 3. & Jambi & $\begin{array}{l}\text { Industri Kelapa Sawit } \\
\text { Industri Karet }\end{array}$ & 10. & $\begin{array}{l}\text { Kalimantan } \\
\text { Timur }\end{array}$ & $\begin{array}{l}\text { Industri Kelapa Sawit } \\
\text { Industri Karet }\end{array}$ \\
\hline 4. & Bangka Belitung & $\begin{array}{l}\text { Industri Pertimahan } \\
\text { Industri Hasil Laut }\end{array}$ & 11. & $\begin{array}{l}\text { Sulawesi } \\
\text { Utara }\end{array}$ & $\begin{array}{l}\text { Pengolahan Kelapa } \\
\text { Pengolahan Hasil Laut }\end{array}$ \\
\hline 5. & Jawa Tengah & $\begin{array}{l}\text { Industri Tekstil } \\
\text { Industri Kayu }\end{array}$ & 12. & Sulawesi & Pengolahan Hasil Laut \\
\hline 6. & DI Yogyakarta & $\begin{array}{l}\text { Industri Kulit } \\
\text { Industri Kayu }\end{array}$ & 13. & $\begin{array}{l}\text { Selatan } \\
\text { Papua Barat }\end{array}$ & $\begin{array}{l}\text { Pengolahan Kakao } \\
\text { Pengolahan Hasil Laut }\end{array}$ \\
\hline 7. & Jawa Timur & $\begin{array}{l}\text { Industri Tekstil } \\
\text { Industri Kayu }\end{array}$ & & & Pengolahan Kayu \\
\hline
\end{tabular}

Sumber : Kementerian Perindustrian 2010 
Peta panduan pengembangan industri unggulan yang telah dikaji dan dievaluasi oleh tim teknis Kementerian Perindustrian, selanjutnya ditetapkan jenis-jenis industri yang menjadi industri unggulan di masing-masing provinsi. Contohnya yaitu jenis industri unggulan Provinsi Yogyakarta menurut Peraturan Menteri Perindustrian No. 138/M-IND/PER/10/2009 yaitu industri pengolahan kulit dan industri pengolahan kayu. Berdasarkan usulan pemerintah provinsi yang telah ditetapkan Kementerian Perindustrian, setiap provinsi tidak hanya memiliki satu jenis industri unggulan tetapi ada juga provinsi yang memiliki dua industri unggulan provinsi.

\section{Daya Saing dan Aglomerasi Industri Unggulan Provinsi}

Suatu industri dikatakan berdaya saing apabila mampu menghasilkan barang dan jasa dengan biaya yang rendah (efisiensi biaya) dan kualitas yang lebih baik sehingga dapat mempertahankan keuntungan dan pangsanya secara berkelanjutan. Ukuran yang digunakan untuk menilai daya saing industri bersifat multi dimensi, yaitu banyak indikator yang dijadikan sebagai ukuran daya saing suatu industri. Indikator tersebut yaitu nilai tambah, produktivitas, profitabilitas, pangsa pasar (market share) dan efisiensi biaya. Namun, ukuran yang sering digunakan untuk mengetahui daya saing suatu industri yaitu indeks Location Quotient (LQ) berbasis output yang diproduksi. Suatu industri dikatakan berdaya saing apabila nilai LQ > 1 yang berarti pangsa output industri di tingkat provinsi lebih besar dibandingkan pangsa output secara nasional. Berdasarkan pengukuran indikator daya saing dengan LQ, sebagian besar industri unggulan provinsi tergolong berdaya saing (nilai
LQ > 1). Akan tetapi, ada juga industri unggulan yang tidak berdaya saing (nilai LQ < 1). Hal ini menunjukkan bahwa belum tentu industri yang menjadi unggulan provinsi tergolong berdaya saing. Analisis LQ yang digunakan untuk menentukan daya saing industri unggulan harus dibandingkan dengan kondisi aglomerasi dari industri unggulan tersebut yaitu dilihat dari nilai Hoover Balassa Index (HBI) sebagai ukuran aglomerasi. Hal ini dikarenakan dengan beraglomerasinya industri tersebut maka akan mengurangi biaya transaksi dan memudahkan untuk berinteraksi dengan industri-industri terkait. Dengan demikian hal ini akan meningkatkan produktivitas industri tersebut dan pada akhirnya akan meningkatkan daya saing industri unggulan di provinsi tersebut (Daryanto 2007).

Berdasarkan hasil analisis pada Gambar 1 menunjukkan bahwa industri unggulan yang berdaya saing tinggi dan teraglomerasi yaitu industri kerajinan barang seni Provinsi Bali dengan nilai LQ 9.32 dan nilai HBI sebesar 11.31. Tingginya daya saing industri tersebut dikarenakan besarnya nilai tambah yang dihasilkan yaitu Rp 220,7 miliar dengan produktivitas sebesar Rp 89,3 juta per tenaga kerja pada tahun 2011. Industri unggulan selanjutnya yaitu industri pengolahan ubi kayu Provinsi Lampung (nilai LQ 9.13 dan HBI 9.52), industri pengolahan hasil laut Provinsi Sulawesi Tengah yang memiliki nilai LQ 8.02 dan HBI 7.28. Industri pengolahan karet Provinsi Sumatera Selatan juga tergolong berdaya saing tinggi dan beraglomerasi dengan nilai LQ 7.54 dan HBI 5.83. Selain itu, industri unggulan yang juga memiliki daya saing tinggi dan tergolong beraglomerasi, yaitu industri tekstil dan produk tekstil Provinsi Jawa Barat yang memiliki nilai LQ sebesar 7.42 dan nilai HBI 8.86. 


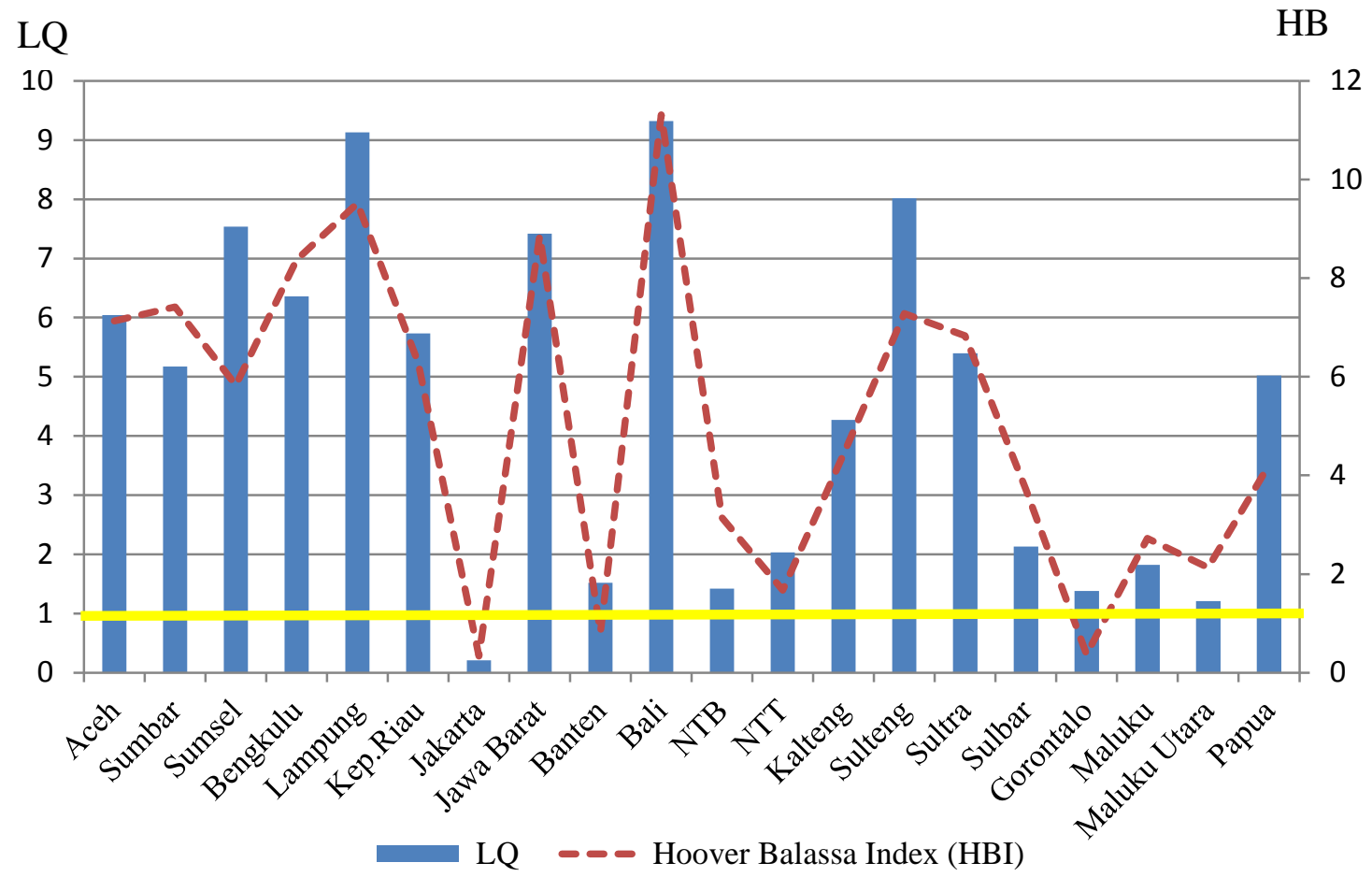

Gambar 1 Nilai LQ dan HBI Industri Unggulan Provinsi Tahun 2011 pada Provinsi dengan Satu Industri Unggulan

Hasil analisis pada provinsi dengan satu industri unggulan, terdapat industri unggulan yang tidak berdaya saing dan juga tidak teraglomerasi yaitu industri kerajinan kayu Provinsi DKI Jakarta dengan nilai LQ 0.21 dan HBI 0.34. Industri kerajinan kayu Provinsi DKI Jakarta tergolong tidak berdaya saing dikarenakan Provinsi DKI Jakarta bukan sebagai wilayah penghasil kayu atau tidak memiliki keunggulan komparatif pada industri kayu. Akan tetapi DKI Jakarta ini hanya sebagai wilayah tempat perakitan dan pemasaran hasil industri kerajinan kayu. Selain itu, hasil analisis juga menunjukkan bahwa hubungan antara daya saing industri dan aglomerasi tidak selalu searah. Hal ini ditunjukkan dengan adanya industri unggulan yang berdaya saing tetapi tidak teraglomerasi. Contoh kasusnya yaitu industri tekstil dan produk tekstil Provinsi Banten yang memiliki nilai LQ 1.52 dan nilai $\mathrm{HBI}$ 0.82. Industri tekstil dan produk tekstil
Provinsi Banten tergolong berdaya saing dengan nilai tambah yang dihasilkan rata-rata mencapai $\mathrm{Rp} 8,6$ triliun. Hal yang sama juga terjadi pada industri hasil perikanan Provinsi Gorontalo yang tergolong berdaya saing (LQ 1.38) tetapi tidak teraglomerasi dengan nilai HBI 0.37. Adapun untuk industri unggulan yang lainnya pada provinsi dengan satu industri unggulan tergolong berdaya saing dan teraglomerasi.

Berdasarkan hasil analisis pada Gambar 2 provinsi dengan dua industri unggulan, sebagian besar kedua industri unggulan pada provinsi tersebut tergolong berdaya saing dan teraglomerasi. Provinsi dengan kedua industri unggulannya tergolong berdaya saing ada 9 provinsi dari 13 provinsi. Provinsi tersebut yaitu Sumatera Utara, Riau, Jambi, Jawa Tengah, Yogyakarta, Kalimantan Barat, Sulawesi Utara, Sulawesi Selatan dan Papua Barat. Sedangkan 4 provinsi lainnya hanya 
satu industri yang tergolong berdaya saing. Pada Provinsi Bangka Belitung industri pertimahan memiliki daya saing yang tinggi (LQ 9.34) dan teraglomerasi (HBI 7.36). Sedangkan industri unggulan yang satunya yaitu industri pengolahan hasil laut tidak berdaya saing karena memiliki nilai LQ sebesar 0.65 tetapi teraglomerasi (HBI 2.57). Hal yang sama terjadi pada Provinsi Kalimantan Selatan dengan industri kelapa sawit memiliki daya saing tinggi dengan nilai LQ 8.63 dan teraglomerasi (HBI 7.95). Sedangkan untuk industri kerajinan batu mulia tergolong tidak berdaya saing karena memiliki nilai LQ sebesar 0.9 tetapi teraglomerasi dengan nilai HBI 1.85. Rendahnya daya saing industri kerajinan batu mulia disebabkan karena Provinsi Kalimantan Selatan lebih memiliki keunggulan komparatif pada industri kelapa sawit. Hal tersebut dibuktikan dengan nilai tambah yang dihasilkan industri kelapa sawit pada tahun 2011 mencapai Rp 8,7 triliun sedangkan industri kerajinan batu mulia hanya menghasilkan nilai tambah sebesar Rp 2,19 triliun.

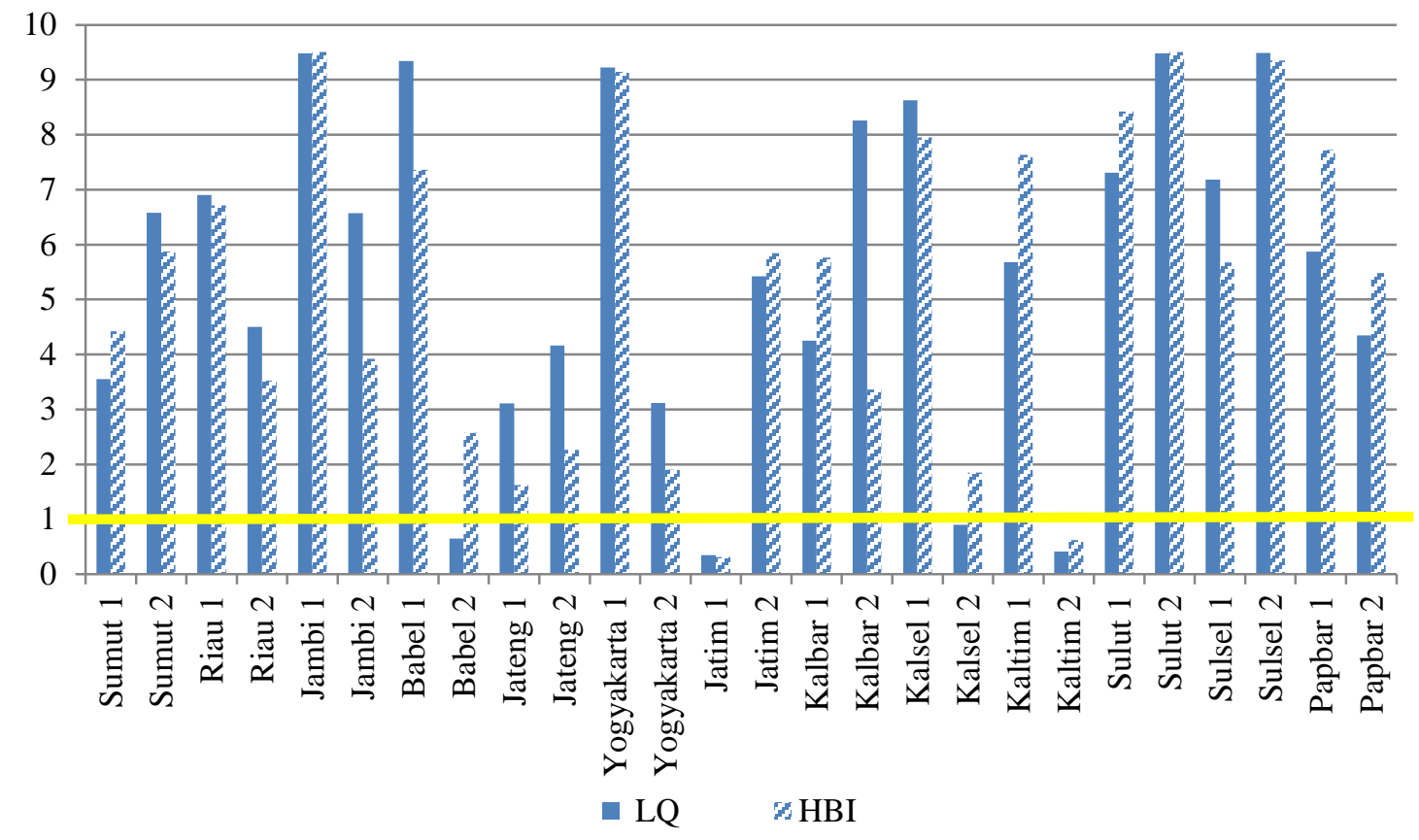

Gambar 2 Nilai LQ dan HBI Industri Unggulan Provinsi Tahun 2011 pada Provinsi dengan Dua Industri Unggulan

Kasus yang sama terjadi pada Provinsi Jawa Timur yang menunjukkan industri pengolahan kayu tergolong berdaya saing dengan nilai LQ 5.42 dan teraglomerasi dengan nilai HBI 5.84 . Sedangkan industri tekstil dan produk tekstil tergolong tidak berdaya saing dan juga tidak beraglomerasi karena memiliki nilai LQ dan HBI masingmasing sebesar 0.35 dan 0.31 . Hal ini ditunjukkan pula dengan rendahnya nilai tambah yang dihasilkan industri tekstil dan produk tekstil yaitu $\mathrm{Rp} 3,8$ triliun sedangkan nilai tambah industri pengolahan kayu mencapai Rp 6,2 triliun pada tahun 2011. Begitu juga yang terjadi pada Provinsi Kalimantan Timur, industri kelapa sawit tergolong berdaya saing dengan nilai LQ 5.68 dan teraglomerasi dengan nilai HBI 7.63. Sedangkan industri pengolahan karet tergolong tidak berdaya saing (LQ 0.41) dan juga tidak teraglomerasi (HBI 0.62) walaupun industri pengolahan karet 
merupakan salah satu industri unggulan Provinsi Kalimantan Timur. Nilai tambah yang dihasilkan industri pengolahan karet hanya mencapai $\mathrm{Rp}$ 44,3 juta sedangkan industri kelapa sawit dapat menghasilkan nilai tambah yang jauh lebih besar yaitu mencapai Rp 3,5 miliar pada tahun 2011.

Pada provinsi dengan kedua industri unggulan yang tergolong berdaya saing, terdapat provinsi dengan salah satu industri unggulannya memiliki daya saing yang jauh lebih tinggi dibandingkan industri unggulan satunya. Contohnya, pada Provinsi Jambi industri pengolahan kelapa sawit memiliki daya saing yang jauh lebih tinggi dengan nilai LQ sebesar 9.48 dibandingkan industri pengolahan yang memiliki nilai LQ sebesar 6.57. Hal ini juga dibuktikan dengan nilai tambah industri pengolahan kelapa sawit yang lebih besar yaitu mencapai Rp 10,78 triliun dibandingkan nilai tambah industri pengolahan karet yang hanya mencapai Rp 2,07 triliun pada tahun 2011. Kasus yang sama terjadi pada Provinsi DI Yogyakarta yang menunjukkan bahwa industri pengolahan kulit jauh lebih berdaya saing dibandingkan industri kerajinan kayu. Nilai LQ industri pengolahan kulit pada tahun 2011 mencapai 9.22 sedangkan pada industri kerajinan kayu hanya sebesar 3.12. Hal ini dikarenakan di Provinsi Yogyakarta terdapat sentra industri pengolahan kulit yaitu di daerah kabupaten Bantul, Sleman dan Kulon Progo.

\section{Hubungan Aglomerasi dengan Daya Saing Industri}

Pengujian hubungan antara aglomerasi dengan daya saing industri unggulan provinsi dilakukan dengan uji Granger Causality. Hipotesis pada uji Granger Causality dalam penelitian ini yaitu :
1. $\mathrm{H}_{0}$ : Aglomerasi tidak memengaruhi daya saing

$\mathrm{H}_{1}$ : Aglomerasi memengaruhi daya saing

2. $\mathrm{H}_{0}$ : Daya saing tidak memengaruhi aglomerasi

$\mathrm{H}_{1}$ : Daya saing memengaruhi aglomerasi

Keputusan $\mathrm{H}_{0}$ ditolak, dilihat dengan cara membandingkan antara nilai probabilitas (prob) dengan taraf nyata $(\alpha)$ 0.05. Jika nilai probabilitasnya lebih kecil dari $\alpha 0.05$ maka keputusannya adalah $\mathrm{H}_{0}$ ditolak yang berarti suatu variabel akan memengaruhi variabel yang lain. Hasil pengujian granger causality dapat dilihat pada Tabel 5.

Tabel 5 Hasil Uji Kausalitas Granger

\begin{tabular}{lcc}
\hline \multicolumn{1}{c}{ Null Hypothesis } & F-stat & Prob \\
\hline HBI does not Granger & 6.31176 & 0.0021 \\
Cause LQ & & \\
$\begin{array}{l}\text { LQ does not Granger } \\
\text { Cause HBI }\end{array}$ & 29.8514 & $2.10^{-12}$ \\
\hline
\end{tabular}

Sumber: Hasil Olahan

$\begin{array}{cr}\text { Hasil pengujian } & \text { kausalitas } \\ \text { Granger menunjukkan } & \text { bahwa }\end{array}$
aglomerasi memengaruhi daya saing industri karena nilai probabilitas yang dihasilkan yaitu 0.0021 lebih kecil dari taraf nyata $(\alpha) \quad 5 \% \quad(0.05)$ sehingga keputusannya tolak $\mathrm{H}_{0}$. Selain itu, daya saing juga memengaruhi aglomerasi industri dengan nilai probabilitas yang dihasilkan $2.10^{-12}$ lebih kecil dari taraf nyata $(\alpha) 5 \%$. Berdasarkan hasil analisis tersebut maka dapat disimpulkan aglomerasi dengan daya saing industri memiliki hubungan kausalitas dua arah, yaitu aglomerasi memengaruhi daya saing industri di Indonesia dan daya saing memengaruhi aglomerasi industri. Kondisi tersebut dapat dijelaskan yaitu ketika industri beraglomerasi di suatu lokasi maka industri tersebut menjadi lebih mudah untuk berinteraksi dengan industri-industri terkait sehingga dapat 
meminimalkan biaya transaksi dan meningkatkan daya saing industri. Hal ini sesuai dengan teori yang menyatakan bahwa industri yang teraglomerasi di suatu daerah akan memperoleh penghematan berupa penurunan biaya transportasi dan biaya transaksi karena lokasi yang saling berdekatan antar industri. Begitu juga, semakin berdaya saing suatu industri maka semakin terdorong untuk beraglomerasi di suatu lokasi dengan tujuan untuk lebih meningkatkan efisiensi. Secara empiris, hal ini ditunjukkan dengan sebagian besar industri unggulan provinsi yang tergolong berdaya saing merupakan industri yang beraglomerasi.

\section{Hasil Estimasi Regresi Panel Data}

Pemilihan model regresi perlu dilakukan sebelum melakukan estimasi. Dalam pemilihan model regresi terbaik digunakan uji Chow dan uji Hausman. Hasil uji Chow menunjukkan bahwa nilai probabilitas sebesar 0.000 lebih kecil dari taraf nyata $(\alpha) 0.05$ sehingga keputusannya $\mathrm{H}_{0}$ ditolak dan kesimpulannya terdapat heterogenitas individu pada model. Dengan demikian, fixed effect model akan memberikan hasil yang lebih baik dalam menangkap heterogenitas individu dibandingkan model pooled least square. Selanjutnya dilakukan uji Hausman dan hasilnya menunjukkan nilai probabilitas Hausman 0.000 lebih kecil dari taraf nyata $\quad(\alpha) \quad 5 \% \quad(0.05) \quad$ sehingga keputusannya $\mathrm{H}_{0}$ ditolak. Hal ini menunjukkan terdapat heterogenitas individu pada model tetapi tidak secara random. Dengan demikian model yang lebih sesuai untuk mengestimasi faktor- faktor yang memengaruhi aglomerasi industri adalah fixed effect model.

Berdasarkan uji kriteria statistik, hasil estimasi pada Tabel 6 menunjukkan probabilitas F-statistik pada persamaan regresi memiliki nilai 0.0000 yang lebih kecil dari taraf nyata (a) 5\% (0.05). Hasil ini menunjukkan setidaknya ada satu variabel bebas yang berpengaruh signifikan terhadap aglomerasi industri. Selanjutnya untuk mengetahui variabel bebas yang berpengaruh signifikan terhadap aglomerasi industri yaitu dilakukan ujit. Hasil uji-t menunjukkan bahwa variabel bebas yang signifikan memengaruhi aglomerasi industri yaitu ukuran perusahaan, nilai tambah, indeks keragaman industri, indeks persaingan industri, indeks daya saing, upah minimum provinsi dan infrastruktur jalan. Hal ini dibuktikan dengan nilai probabilitas pada masing-masing variabel bebas tersebut lebih kecil daripada taraf nyata $5 \%$. Sementara itu, variabel pendapatan daerah per kapita, proporsi investasi total dan dummy tahun pelaksanaan Pelayanan Terpadu Satu Pintu (PTSP) tidak berpengaruh signifikan terhadap aglomerasi industri.

Hasil estimasi juga menunjukkan nilai Adjusted $\mathrm{R}^{2}$ (koefisien determinasi) yang diperoleh yaitu sebesar 0.7668 . Nilai Adjusted $\mathrm{R}^{2}$ (koefisien determinasi) ini digunakan sebagai ukuran kesesusaian model (goodness of fit). Nilai Adjusted $\mathrm{R}^{2}$ ini menunjukkan bahwa $76.68 \%$ keragaman variabel dependen (aglomerasi industri) mampu dijelaskan oleh variabel-variabel bebas yang ada di dalam model. Sedangkan sisanya yaitu sebesar $23.32 \%$ dijelaskan oleh faktor lain di luar model. 
Tabel 6 Hasil estimasi faktor-faktor yang memengaruhi aglomerasi industri

\begin{tabular}{|c|c|c|c|}
\hline Variabel Bebas & Koefisien & Prob & Elastisitas \\
\hline Konstanta (C) & -4.9724 & 0.8993 & \\
\hline Ukuran perusahaan (SIZ) & -3.2395 & $0.0000 *$ & -0.159 \\
\hline Nilai Tambah (NT) & 0.9601 & $0.0193 *$ & 0.047 \\
\hline Proporsi investasi total (INVEST) & 0.4429 & 0.8634 & 0.001 \\
\hline Indeks keragaman industri (RID) & -18.340 & $0.0000 *$ & -0.687 \\
\hline Indeks persaingan (IPS) & 0.5769 & $0.0023^{*}$ & 0.074 \\
\hline Indeks daya saing (LQ) & 0.1222 & $0.0002 *$ & 0.106 \\
\hline Upah minimum provinsi (UMP) & -2.8836 & $0.0370 *$ & -0.141 \\
\hline Pendapatan regional per kapita (PDRBPK) & 2.6081 & 0.4006 & 0.128 \\
\hline Infrastruktur jalan $(\mathrm{J})$ & 3.5164 & $0.0005^{*}$ & 0.172 \\
\hline Dummy pelayanan birokrasi (DUMPTSP) & -0.2473 & 0.5542 & -0.005 \\
\hline Adjusted $\mathrm{R}^{2}$ & 0.7668 & & \\
\hline Prob (F-statistic) & 0.0000 & & \\
\hline
\end{tabular}

Keterangan : * signifikan pada taraf nyata 5 persen $(\alpha=0.05)$

Faktor-Faktor yang Memengaruhi Aglomerasi Industri Unggulan

\section{Ukuran Perusahaan}

Ukuran perusahaan (SIZ) sebagai ukuran skala ekonomi signifikan mempengaruhi terjadinya aglomerasi industri secara negatif. Nilai elastisitas sebesar -0.159 menunjukkan peningkatan skala ekonomi 1 persen akan menurunkan indeks aglomerasi industri sebesar 0.159 persen. Hasil ini tidak sesuai dengan hipotesis teori New Economic Goegraphy yang menyatakan industriindustri yang teraglomerasi berhubungan positif dengan skala ekonomi. Hal ini dikarenakan justru perusahaan-perusahaan industri yang berskala ekonomi kecil terdorong untuk beraglomerasi dengan tujuan mendapatkan penghematan lokalisasi (economies of localization) karena berlokasi dekat dengan industri lain. Lokasi yang saling berdekatan antar industri dapat meminimumkan biaya transportasi, biaya transaksi dan produksi sehingga output yang dihasilkan lebih besar dan terjadi efisiensi produksi sehingga industriindustri yang awalnya berskala kecil dapat menikmati adanya economies of scale (penghematan karena berproduksi dalam skala yang besar). Hal ini pada akhirnya dapat menjadikan industri-industri tersebut menjadi berdaya saing (Lestari 2010).

\section{* Nilai Tambah}

Nilai tambah mempunyai pengaruh signifikan dengan hubungan yang positif terhadap pembentukan aglomerasi industri manufaktur. Nilai elastisitasnya adalah 0.047 yang artinya peningkatan nilai tambah sebesar 1 persen akan meningkatkan terjadinya aglomerasi industri sebesar 0.047 persen cateris paribus. Nilai tambah merupakan selisih antara nilai output yang dihasilkan dengan nilai input yang dibutuhkan suatu perusahaan industri besar dan sedang. Semakin tinggi nilai tambah yang dihasilkan suatu perusahaan industri besar dan sedang maka akan semakin besar efisiensi yang dihasilkan oleh industri tersebut. Dengan demikian nilai tambah menunjukkan efisiensi dari suatu 
industri untuk berkembang. Peningkatan nilai tambah dapat disebabkan oleh kemajuan teknologi yang berkembang di wilayah tersebut. Hal ini sesuai dengan perspektif modern yang menyatakan bahwa untuk meningkatkan produktivitas pekerja, transfer teknologi antar perusahaan sangat dibutuhkan untuk meningkatkan nilai tambah yang dihasilkan.

\section{* Proporsi Investasi Total}

Proporsi investasi total tidak signifikan berpengaruh terhadap pembentukan aglomerasi industri di suatu daerah. Hal ini dikarenakan kontribusi realisasi total nilai investasi dalam negeri dan asing terhadap nilai PDRB yang dihasilkan di tiap provinsi sangat kecil sehingga tidak memengaruhi terjadinya aglomerasi industri. Proporsi investasi total ini memiliki hubungan yang positif dengan aglomerasi industri dan sesuai dengan teori walaupun tidak berpengaruh secara statistik.

\section{* Indeks Keragaman Industri} Indeks keragaman industri (relative industrial diversity) berpengaruh signifikan secara negatif terhadap pembentukan aglomerasi industri unggulan. Nilai elastisitas sebesar -0.687 menunjukkan setiap kenaikan 1 persen indeks keragaman industri maka akan menurunkan terjadinya aglomerasi industri sebesar 0.687 persen. Kenaikan indeks keragaman berarti penurunan tingkat keragaman industri. Hal ini sesuai dengan hipotesis bahwa keragaman industri di suatu wilayah menjadi faktor yang menstimulus terjadinya aglomerasi. Hipotesis juga selaras dengan urbanization economies bahwa keragaman industri di suatu wilayah akan mendorong eksplorasi dan berperan dalam penyebaran pengetahuan (knowledge spillover) antarindustri dan pertumbuhan industri. Menurut Santoso dan Prabatmodjo (2012) menyatakan bahwa aglomerasi industri terbentuk karena berkumpulnya beragam industri pada suatu lokasi tertentu yang akhirnya akan menghasilkan output yang heterogen. Selain itu, industri akan lebih inovatif dan tumbuh lebih cepat apabila berlokasi pada wilayah dengan industri yang beraneka ragam. Hal senada diungkapkan oleh Ellison et al (2010) bahwa diversifikasi industri akan mendorong pertumbuhan industri melalui sebaran pengetahuan (knowledge spillover) dari industri lain yang berkaitan dengan industri tersebut.

\section{* Indeks Persaingan Industri}

Indeks persaingan industri (IPS) yang digunakan untuk mendekati struktur pasar berpengaruh positif terhadap pembentukan aglomerasi. Nilai elastisitas indeks persaingan ini sebesar 0.074 yang berarti setiap kenaikan indeks persaingan sebesar 1 persen maka akan meningkatkan terjadinya aglomerasi industri sebesar 0.074. Hasil tersebut menunjukkan bahwa kompetisi yang semakin tinggi akan memiliki dampak dalam mempercepat terjadinya aglomerasi industri. Hal ini sesuai dengan hipotesis bahwa semakin tinggi tingkat persaingan industri maka setiap produsen akan menggunakan strategi aglomerasi dan membentuk konsentrasi secara spasial guna meningkatkan tingkat produksi sehingga dapat tercapai efisiensi produksi. Kondisi ini menunjukkan bahwa semakin besar struktur pasar di suatu daerah maka akan tercipta suatu konsentrasi spasial yang akan membentuk aglomerasi industri dengan tujuan untuk meningkatkan daya saing dan pangsa pasarnya. 


\section{- Indeks Daya Saing}

Daya saing industri sebagai ukuran pangsa output industri unggulan di suatu provinsi mempunyai pengaruh positif terhadap terjadinya aglomerasi industri. Nilai elastisitas daya saing sebesar 0.106 menunjukkan bahwa setiap terjadi kenaikan pangsa output industri atau terjadi peningkatan daya saing industri sebesar 1 persen maka akan meningkatkan terjadinya aglomerasi sebesar 0.106 persen. Hal ini sesuai dengan hipotesis bahwa semakin berdaya saing suatu industri yang berarti industri unggulan provinsi tersebut memiliki pangsa output yang lebih besar daripada pangsa output industri di tingkat nasional, maka semakin terdorong untuk beraglomerasi. Dorongan untuk beraglomerasi dikarenakan untuk lebih meningkatkan efisiensi karena adanya penghematan akibat lokasi antarindustri yang saling berdekatan.

\section{* Upah Minimum Provinsi}

Upah Minimum Provinsi (UMP) digunakan untuk mengkaji pengaruh kebijakan pemerintah yang berkaitan dengan biaya tenaga kerja terhadap terjadinya aglomerasi industri di suatu daerah. Upah Minimum Provinsi berpengaruh negatif terhadap aglomerasi industri dengan nilai elastisitas sebesar -0.141. Hal ini berarti kebijakan UMP yang rendah mendukung dalam peningkatan aglomerasi industri karena ketika terjadi penurunan upah minimum sebesar 1 persen maka akan mendorong peningkatan aglomerasi industri sebesar 0.141 persen. Hasil ini sesuai dengan hipotesis yang digunakan yaitu UMP yang semakin kecil akan mempercepat terjadinya aglomerasi industri unggulan.

Teori lokasi menyatakan bahwa faktor biaya tenaga kerja merupakan faktor dominan dalam penentuan lokasi industri di samping biaya transportasi. Hasil yang diperoleh sesuai dengan teori lokasi yang menyatakan bahwa sebuah pabrik akan memilih berlokasi di daerah dengan tingkat upah yang rendah untuk meminimumkan biaya produksi (Simandjorang 2010). Kenaikan upah tenaga kerja yang signifikan menyebabkan penurunan tingkat aglomerasi industri. Hal ini dikarenakan industri yang teraglomerasi di berbagai wilayah di Indonesia merupakan industri yang memiliki kecenderungan padat karya. Jika upah tenaga kerja meningkat maka permintaan tenaga kerja akan berkurang dan menyebabkan berpindahnya suatu lokasi industri sehingga aglomerasi industri (konsentrasi spasial) akan menurun.

\section{- Pendapatan Regional per Kapita}

Pendapatan regional per kapita sebagai ukuran daya beli masyarakat tidak signifikan berpengaruh terhadap terjadinya aglomerasi industri. Hal ini dikarenakan pendapatan regional per kapita lebih berpengaruh terhadap peningkatan nilai produksi karena berkaitan dengan permintaan dari masyarakat (daya beli masyarakat). Sedangkan terhadap keputusan suatu industri untuk beraglomerasi atau terkonsentrasi secara spasial di suatu lokasi, pendapatan regional per kapita tidak berpengaruh secara langsung. Hal ini dikarenakan keputusan industri untuk beraglomerasi lebih dipengaruhi oleh ketersediaan tenaga kerja yang merupakan input utama dalam kegiatan produksi dan besarnya upah yang berdampak pada biaya produksi.

\section{* Infrastruktur Jalan}

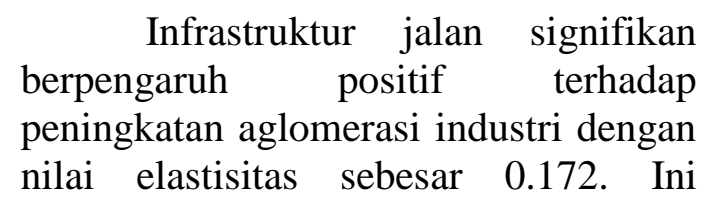


artinya setiap terjadi penambahan panjang jalan dengan kondisi baik dan sedang sebesar 1 persen maka akan meningkatkan terjadinya aglomerasi industri sebesar 0.172 persen. Hasil ini sesuai dengan teori klasik aglomerasi yang menyatakan bahwa peningkatan jalan dengan kondisi baik dan sedang akan lebih memperlancar kegiatan ekonomi karena biaya transportasi menjadi murah (penghematan secara eksternal) sehingga dapat mempercepat pembentukan aglomerasi. Panjang jalan dengan kondisi baik mempunyai peranan yang cukup penting dalam kegiatan perekonomian. Distribusi faktor produksi maupun barang dan jasa hasil produksi sangat tergantung dari keberadaan infrastruktur jalan yang baik. Secara spasial, mobilitas manusia dan hasil produksi ini menentukan kemajuan suatu wilayah. Hal ini karena infrastruktur jalan yang baik dapat mendorong interaksi dan keterbukaan dengan wilayah lain sehingga dapat meningkatkan pangsa pasar baik faktor produksi maupun hasil produksi.

\section{* Pelayanan Birokrasi}

Variabel dummy tahun pelaksanaan Pelayanan Terpadu Satu Pintu (PTSP) sebagai ukuran kondisi layanan birokrasi di tiap provinsi menunjukkan hasil tidak signifikan memengaruhi terjadinya aglomerasi industri. Hal ini dikarenakan kondisi pelayanan terpadu ini tidak berhubungan secara langsung dengan pembentukan aglomerasi. Akan tetapi kondisi pelayanan ini akan berpengaruh secara langsung terhadap kelancaran kegiatan ekonomi khususnya kegiatan industri, terkait dengan perizinan usaha dan penanaman modal. Kondisi pelayanan birokrasi yang berdampak terhadap kelancaran kegiatan industri pada akhirnya dapat meningkatkan nilai tambah dan daya saing industri yang selanjutnya baru akan memengaruhi terjadinya aglomerasi industri.

\section{PENUTUP}

\section{Kesimpulan}

Berdasarkan hasil penelitian mengenai keterkaitan antara daya saing industri unggulan provinsi dengan aglomerasi industri di Indonesia pada kurun waktu 2004 hingga 2011, maka dapat diambil beberapa kesimpulan sebagai berikut:

1. Sebagian besar industri unggulan provinsi tergolong berdaya saing dan teraglomerasi (84.78\%). Industri unggulan yang tergolong berdaya saing tersebut $60.87 \%$ merupakan industri pengolahan yang berbasis pertanian (agroindustri) dari seluruh jenis industri unggulan provinsi di Indonesia.

2. Berdasarkan hasil analisis kausalitas granger, daya saing dan aglomerasi industri memiliki hubungan dua arah yang positif. Industri yang teraglomerasi akan memperoleh penghematan berupa penurunan biaya-biaya sehingga dapat meningkatkan daya saing. Begitu juga, semakin berdaya saing suatu industri maka semakin terdorong untuk beraglomerasi di suatu lokasi dengan tujuan untuk lebih meningkatkan efisiensi.

3. Faktor-faktor yang secara positif memengaruhi aglomerasi industri unggulan provinsi yaitu nilai tambah, indeks persaingan industri (struktur pasar), infrastruktur jalan dan indeks daya saing industri. Ukuran perusahaan (skala ekonomi), keragaman industri dan tingkat upah berpengaruh negatif terhadap aglomerasi. Proporsi investasi total, pendapatan regional per kapita, dan kebijakan pelaksanaan Pelayanan Terpadu 
Satu Pintu (PTSP) tidak berpengaruh secara statistik terhadap aglomerasi industri.

\section{Saran}

Berdasarkan hasil pembahasan, maka beberapa saran yang dapat diberikan adalah sebagai berikut :

1. Pengembangan industri manufaktur berbasis unggulan daerah merupakan salah satu cara yang dapat digunakan pemerintah untuk terus meningkatkan daya saing industri secara nasional. Potensi yang dimiliki masing-masing daerah jika dikombinasikan dengan pendekatan aglomerasi maka industri-industri unggulan tersebut dapat berkembang dan menarik industri-industri lainnya sehingga dapat meningkatkan pertumbuhan industri dan pendapatan daerah yang bersangkutan.

2. Infrastruktur jalan dan tingkat upah berpengaruh besar terhadap aglomerasi industri sehingga kebijakan mengenai tingkat upah harus diawasi dan diatur oleh pemerintah. Selain itu, dalam rangka pengembangan industri dan pemerataan pembangunan maka perlu adanya pemerataan fasilitas infrastruktur khususnya infrastruktur jalan. Hal ini dikarenakan kondisi jalan yang baik di tiap daerah akan memudahkan segala aktivitas ekonomi khususnya kegiatan industri sehingga mempercepat penyebaran industri.

3. Berkaitan dengan perekonomian Indonesia dengan kontribusi terbesar berasal dari sektor industri dan masih bersifat padat karya (labor intensive) maka untuk mendorong pertumbuhan ekonomi diprioritaskan pada industri- industri yang banyak menyerap tenaga kerja.

\section{DAFTAR PUSTAKA}

Alkay E, and Hewings G. 2010. The Determinants of Agglomeration for The Manufacturing Sector In The Istanbul Metropolitan Area. Original Paper Springer Vol. 48 : 225-245.

Baltagi, B.H. 2005. Econometric Analysis of Panel Data. John Wiley \& Sons LTD. London

[BPS] Badan Pusat Statistik. 2013. Statistik Indonesia 2013 : Distribusi Persentase Produk Domestik Bruto (PDB) Atas Dasar Harga Berlaku Menurut Lapangan Usaha Tahun 20092012. Badan Pusat Statistik : Jakarta.

Capello, R. 2007. Regional Economics. Routledge : New York.

Daryanto, A. 2007. Peningkatan Dayasaing Industri Peternakan. Jakarta (ID) : PT. Permata Wacana Lestari.

Deichmann U, Kaiser K, Lall S, dan Shalizi Z. 2005. Agglomeration, Transport, and Regional Development in Indonesia. World Bank Policy Research Working Paper 3477. January 2005

Ellison G, Glaeser E, dan Kerr W. 2010. What Causes Industry Agglomeration? Evidence from Coagglomeration Patterns. American Economic Review Vol. $100: 1195-1213$.

Gujarati, D. 2004. Basics Econometrics. Fourth Edition.The Megraw-Hill Companies. New York.

Kementerian Perindustrian. 2010. Perkembangan Penyusunan Peta Panduan (Roadmap) Pengembangan Industri Unggulan Provinsi. http://www.kemenperin.go.id 
[diakses tanggal 27 Februari 2014].

Kementerian Perindustrian 2011. Statistik Industri Menurut Provinsi di Indonesia. Pusat Data dan Informasi Kementerian Perindustrian : Jakarta.

Kolehmainen, J. 2002. Territorial Agglomeration as a Local Innovation Environment. MIT Industrial Performance Centre. Working Paper No. 03002.

Kuncoro, M. 2002. Analisis Spasial dan Regional. UPP AMP YKPN : Jogjakarta.

Kuncoro, M. 2004. Otonomi dan Pembangunan Daerah : Reformasi, Perencanaan, Strategi dan Peluang. Erlangga: Jakarta.

Kuncoro M dan Wahyuni S. 2009. FDI Impact On Industrial Agglomeration : The Case of Java, Indonesia. Journal of Asia Business Studies : 65-77.

Landiyanto, E.A. 2005. Konsentrasi Spasial Industri Manufaktur Tinjauan Empiris di Kota Surabaya. Jurnal Ekonomi dan Pembangunan Indonesia, Volume 5 No. 02 Januari, hal 75-90.

Lestari, E.P. 2010. Penguatan Ekonomi Industri Kecil dan Menengah Melalui Platform Klaster Industri. Jurnal Organisasi dan Manajemen. Volume. 6 No. 2 September, Hal 145-157.

Purwaningsih. 2011. Tren Konsentrasi dan Faktor-Faktor yang
Mempengaruhi Aglomerasi

Industri Manufaktur Besar Sedang di Jawa Barat [tesis]. Bogor (ID) : Institut Pertanian Bogor.

Santoso A.B dan Prabatmodjo H. 2012. Aglomerasi Industri dan Perubahan Sosial Ekonomi di Kabupaten Bekasi. Jurnal Perencanaan Wilayah dan Kota SAPPK V1 N2.

Santoso E.B dan Ferdyansyah D. 2013. Pola Spasial Kegiatan Industri Unggulan di Provinsi Jawa Timur (Studi Kasus : Subsektor Industri Tekstil, Barang Kulit dan Alas Kaki). Jurnal Teknik Pomits. Vol. 2 No. $1: 31-36$.

Simandjorang, W.E. 2010. Pembangunan Regional : Studi Kasus Perspektif Kawasan Industri Kuala Tanjung. UI Press: Jakarta.

Tambunan, T. 2001. Industrialisasi di Negara Sedang Berkembang : Kasus Indonesia. Ghalia Indonesia : Jakarta.

Tian, Zheng. 2013. Measuring Agglomeration Using the Standardized Location Quotient with a Bootstrap Method. The Journal of Regional Analysis and Policy. Vol 43 (2) : 186-197.

Vidyatmoko D, Rosadi H dan Taufiq R. 2011. Peningkatan Daya saing Industri : Metode dan Studi Kasus. BPPT Press : Jakarta. 